\title{
Upregulation of the Rat Cardiac Sodium Channel by In Vivo Treatment with a Class I Antiarrhythmic Drug
}

\author{
Mohammed Taouis, Robert S. Sheldon, and Henry J. Duff \\ Cardiovascular Research Group, Department of Medicine, University of Calgary, Calgary, Alberta T2N 4N1, Canada
}

\begin{abstract}
Class I antiarrhythmic drugs inhibit the sodium channel by binding to a drug receptor associated with the channel. In this report we show that in vivo administration of the class I antiarrhythmic drug mexiletine to rats induces sodium channel upregulation in isolated cardiac myocytes. The number of sodium channels was assessed with a radioligand assay using the sodium channel-specific toxin $\left[{ }^{3} \mathrm{H}\right]$ batrachotoxinin benzoate ( $\left.\left.{ }^{3} \mathrm{H}\right] \mathrm{BTXB}\right)$. The administration of mexiletine to rats induced a dose-dependent increase in $\left.{ }^{3} \mathrm{H}\right] \mathrm{BTXB}$ total specific binding $\left(B_{\max }\right)$ on isolated cardiac myocytes. Sodium channel numbers were $15 \pm 5,29 \pm 9$, and $54 \pm 4 \mathrm{fmol} / 10^{5}$ cells after $3 \mathrm{~d}$ treatment with $0,50 \mathrm{mg} / \mathrm{kg}$ per $\mathrm{d}$, and $150 \mathrm{mg} / \mathrm{kg}$ per $\mathrm{d}$ mexiletine $(P$ $<0.001$, analysis of variance). Sodium channel number increased monoexponentially to a steady-state value within $3 \mathrm{~d}$ with a half-time of increase of $1.0 \mathrm{~d}$. After cessation of treatment with mexiletine the number of sodium channels returned to normal within $12 \mathrm{~d}$. Finally, treatment with mexiletine altered only sodium channel number; the $K_{d}$ for $\left[^{3} H\right] B T X B$ and the $\mathrm{IC}_{\mathbf{5 0}}$ for mexiletine were not different for myocytes prepared from control and mexiletine-treated rats. (J. Clin. Invest. 1991. 88:375-378.) Key words: mexiletine • cardiac cells • sodium channel $\bullet$ batrachotoxin $\bullet$ drug receptor
\end{abstract}

\section{Introduction}

The pharmacologic treatment of cardiac arrhythmias is frequently limited by resistance to therapy with Class I antiarrhythmic drugs. Class I drugs block the cardiac sodium channel by binding to a receptor associated with the channel. We have previously reported that some patients who respond to intravenous Class I drugs subsequently develop drug resistance during chronic oral treatment (1). One possible explanation for this finding is that drug therapy induces drug resistance. We hypothesized that a mechanism of resistance to Class I drugs might be a drug-induced time-dependent increase in the number of cardiac sodium channels.

Accordingly, we determined whether treatment of rats for 1-6 d with the Class I antiarrhythmic drug mexiletine induced an increase in the number of cardiac sodium channels. The Class I drug mexiletine (2) was selected for administration to

\footnotetext{
Address correspondence to Dr. Robert Sheldon, Department of Medicine, University of Calgary, 3330 Hospital Drive Northwest, Calgary, Alberta T2N 4N1, Canada.

Received for publication 10 July 1990 and in revised form 24 January 1991.
}

J. Clin. Invest.

(C) The American Society for Clinical Investigation, Inc.

0021-9738/91/08/0375/04 \$2.00

Volume 88, August 1991, 375-378 rats because it has a long biological half-life, it is water soluble and therefore should be easily washed out from isolated cardiac myocytes, and it is electrophysiologically similar to the prototypic Class I drug lidocaine. The number of sodium channels was assessed with a conventional radioligand assay (3) using the sodium channel-specific toxin $\left[{ }^{3} \mathrm{H}\right]$ batrachotoxinin benzoate $\left(\left[{ }^{3} \mathrm{H}\right] \mathrm{BTXB}\right){ }^{1}$

\section{Methods}

\section{Cardiac myocyte preparation}

Cardiac myocytes were isolated from adult male Sprague-Dawley rats (200-250 g) (Charles River Breeding Laboratories, Inc., St. Constant, Quebec) by collagenase dispersion using the method of Kryski et al. (4). This method routinely yielded $\sim 60 \mathrm{mg}$ (dry wt) of myocytes, which corresponds to $1.2 \times 10^{7}$ cells $(4,5)$. The cells were $85-90 \%$ viable rod-shaped cells that excluded trypan blue and were tolerant of $1 \mathrm{mM}$ calcium.

\section{$\left[{ }^{3} H\right] B T X B$ equilibrium binding}

Equilibrium binding assays were performed as described previously (3). Myocytes $\left(6 \times 10^{5}\right.$ cells/assay) in $50 \mu$ l of incubation buffer (MEM with $50 \mu \mathrm{M} \mathrm{CaCl}_{2}$ and $1 \%$ dialyzed BSA) were incubated with $1.3 \mu \mathrm{M}$ sea anemone toxin (ATX), $0.13 \mathrm{mM}$ tetrodotoxin (TTX), and various concentrations of $\left[{ }^{3} \mathrm{H}\right] \mathrm{BTXB}$ for $55 \mathrm{~min}$ at $37^{\circ} \mathrm{C}$.

TTX was added to prevent depolarization induced by sodium influx; without TTX, no specific binding is observed $(6,7)$. Assays were done in parallel with tubes containing $0.4 \mathrm{mM}$ aconitine to define the nonspecific binding. Reactions were stopped by adding $10 \mathrm{ml}$ of KrebsHenseleit BSA buffer $(127 \mathrm{mM} \mathrm{NaCl}, 2.33 \mathrm{mM} \mathrm{KCl}, 1.3 \mathrm{mM}$ $\mathrm{KH}_{2} \mathrm{PO}_{4}, 1.23 \mathrm{mM} \mathrm{MgSO}_{4}, 25 \mathrm{mM} \mathrm{NaHCO}, 10 \mathrm{mM}$ glucose, $50 \mu \mathrm{M}$ $\mathrm{CaCl}_{2}$, and $1 \% \mathrm{BSA}$ ) that was equilibrated with $95 \% \mathrm{O}_{2}-5 \% \mathrm{CO}_{2}$, incubated at $37^{\circ} \mathrm{C}$ for $1 \mathrm{~min}$, filtered through a GF/C 24-mm filter (Whatman Laboratory Products, Inc., Clifton, NJ), and washed four times with $5 \mathrm{ml}$ of rinse buffer $(25 \mathrm{mM}$ Tris $\mathrm{HCl}, \mathrm{pH} 7.4,130 \mathrm{mM} \mathrm{NaCl}, 5.5$ $\mathrm{mM}$ glucose, and $50 \mu \mathrm{M} \mathrm{CaCl}_{2}$ ). The filters were dried and counted in Econofluor scintillation fluid (New England Nuclear, Mississauga, Ontario). The retained radioactivity represents $\left[{ }^{3} \mathrm{H}\right] \mathrm{BTXB}$ bound to myocytes.

The rationale for the incubation and the filtration conditions have previously been described (7). The conditions provide a maximal reduction in background and scatter with a minimal reduction in specific binding. The total wash time is $45 \mathrm{~s}$. Initial control experiments showed that under these conditions $<10 \%$ of the specifically bound $\left[{ }^{3} \mathrm{H}\right] \mathrm{BTXB}$ dissociated from the complex. Under these reaction conditions about $60-75 \%$ of total radioactivity retained on filters is bound specifically to the $\left[{ }^{3} \mathrm{H}\right] \mathrm{BTXB}$ binding site.

\section{Protocols}

Dose-dependence of channel numbers. Three doses of mexiletine (placebo, 50 or $150 \mathrm{mg} / \mathrm{kg}$ per d) were administered subcutaneously in 0.5 $\mathrm{ml}$ saline at $0900 \mathrm{~h}$ daily. The doses of mexiletine used in this study were 3- to 20 -fold less than the $\mathrm{LD}_{\mathrm{s0}}$ dosage range $(480-1,080 \mathrm{mg} / \mathrm{kg}$

1. Abbreviations used in this paper: ATX, sea anemone toxin; $\mathrm{B}_{\max }$, total specific binding of $\left[{ }^{3} \mathrm{H}\right] \mathrm{BTXB} ;\left[{ }^{3} \mathrm{H}\right] \mathrm{BTXB}$, batrachotoxinin benzoate; TTX, tetrodotoxin. 
per d) (2). After $3 \mathrm{~d}$ of in vivo treatment pairs of placebo- and mexiletine-treated rats were killed and cardiac myocytes prepared for radioligand studies.

Time-dependence of channel expression. Pairs of rats were randomly assigned to receive placebo or mexiletine $(50 \mathrm{mg} / \mathrm{kg}$ per d) daily and were killed after $0,1,2,3,4$, and $6 \mathrm{~d}$ of treatment for preparation of myocytes for radioligand analysis.

Time-dependence of recovery to baseline. Pairs of rats were randomly assigned to placebo or mexiletine $(50 \mathrm{mg} / \mathrm{kg}$ per d) treatment for $3 \mathrm{~d}$, after which treatment was discontinued. Pairs of rats were killed 0 , $2,4,5,6$, and $12 \mathrm{~d}$ after treatment was discontinued and myocytes were prepared for radioligand studies.

\section{Study design and statistical analysis}

To minimize day-to-day variability in rats and drug and toxin preparations, all experiments were done in a paired fashion. Pairs of weightmatched adult male Sprague-Dawley rats (200-250 g) were randomly assigned to receive either subcutaneous placebo or mexiletine. This paired approach was used in all phases of this investigation including assessment of dose-dependence, time-dependence, time-dependence of recovery of channel number, and the effects of chronic therapy on the characteristics of in vitro ligand/receptor interactions. Data are presented as mean $\pm 1 \mathrm{SD}$. Analysis of variance was used to assess the significance of the dose and time-dependent changes in sodium channel number.

\section{Measurement of ouabain-sensitive sodium, potassium- activated ATPase}

Freshly excised rat hearts were each minced in $2.5 \mathrm{ml}$ solution I (127 $\mathrm{mM} \mathrm{KCl}, 10 \mathrm{mM}$ Hepes-Tris pH 7.2, $1 \mathrm{mM}$ PMSF, 1 mM iodoacetamide, $1 \mathrm{mM}$ EGTA, $0.1 \mu \mathrm{g} / \mathrm{ml}$ pepstatin) and homogenized with a Polytron (45-s duration at full power; Brinkman Instruments [Canada] Ltd., Rexdale, Ontario). The homogenate was centrifuged at $600 \mathrm{~g}$ at $4^{\circ} \mathrm{C}$ for $10 \mathrm{~min}$ and the resulting pellet was then homogenized in $5 \mathrm{ml}$ solution I. After centrifugation at $4^{\circ} \mathrm{C}$ for $10 \mathrm{~min}$ at $10,000 \mathrm{~g}$ the resultant pellet was then homogenized in $5 \mathrm{ml}$ solution II ( $300 \mathrm{mM}$ sucrose, $10 \mathrm{mM}$ Hepes-Tris $\mathrm{pH}$ 7.2). This suspension was centrifuged twice at $4^{\circ} \mathrm{C}$ at $7,000 \mathrm{~g}$ for $20 \mathrm{~min}$ and the supernatant fluid was then centrifuged at $275,000 \mathrm{~g}$ for $1 \mathrm{~h}$ at $4^{\circ} \mathrm{C}$. The resulting pellet was then assayed for both protein concentration and ouabain-sensitive sodium, potassium-activated ATPase by the method of Monahan and Jones (8). Each heart was processed separately.

\section{Analysis of protein and mexiletine}

Protein concentration was determined by the Lowry method (9). To assess the concentration of mexiletine produced during subcutaneous treatment, rats were killed $2 \mathrm{~h}$ and $24 \mathrm{~h}$ after its administration. The chest was opened, the heart punctured, and a $2-\mathrm{ml}$ blood sample removed. Serum concentrations of mexiletine were assayed using a high performance chromatographic method (10).

\section{Drugs and chemicals}

[ $\left.{ }^{3} \mathrm{H}\right] \mathrm{BTXB}$ (specific radioactivity $56.8 \mathrm{Ci} / \mathrm{mmol}$ ) was obtained from New England Nuclear, Boston, MA. Mexiletine was a gift of Boehringer Ingelheim Canada, Burlington, Ontario. Sea anemone toxin II, tetrodotoxin, and aconitine were purchased from Sigma Chemical Co., St. Louis, MO.

\section{Results}

Dose-dependent effect of mexiletine treatment on sodium channel number. Paired rats were treated for $3 \mathrm{~d}$ with placebo, 50 $\mathrm{mg} / \mathrm{kg}$ per d or $150 \mathrm{mg} / \mathrm{kg}$ per $\mathrm{d}$ of mexiletine and $\left[{ }^{3} \mathrm{H}\right] \mathrm{BTXB}$ binding to freshly isolated myocytes was subsequently assessed. Fig. 1 illustrates a typical experiment. The total specific binding $\left(B_{\max }\right)$ of $\left[{ }^{3} \mathrm{H}\right] \mathrm{BTXB}$ increased in a dose-dependent fashion in cardiac myocytes after mexiletine treatment. Table I presents the mean dose-dependent effects of mexiletine treatment

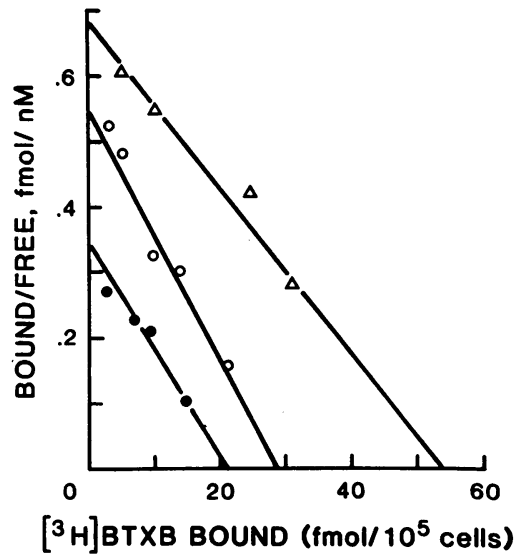

Figure 1. Effect of subcutaneous mexiletine administration on the number of sodium channels on rat myocytes. Myocytes were isolated using collagenase digestion from control rats (๑) and from rats treated for $3 \mathrm{~d}$ with $50 \mathrm{mg} / \mathrm{kg}$ per d (o) or $150 \mathrm{mg} / \mathrm{kg}$ per d mexiletine $(\Delta)$. Myocytes $\left(6 \times 10^{5}\right.$ per tube $)$ then were incubated with $1.3 \mu \mathrm{M}$ ATX, 0.13 mM TTX, and various concentrations of $\left[{ }^{3} \mathrm{H}\right] \mathrm{BTXB}$ in $50 \mu \mathrm{l}$. Assays were done in parallel with tubes containing $0.5 \mathrm{mM}$ aconitine to define nonspecific binding. Each point represents the mean of duplicate determinations. Linear regression best-fit values for control cells are $B_{\max } 21 \mathrm{fmol} / 10^{5}$ cells and $K_{\mathrm{d}} 28 \mathrm{nM}$. Best-fit values for rats that received $50 \mathrm{mg} / \mathrm{kg}$ per $d$ or $150 \mathrm{mg} / \mathrm{kg}$ per $d$ of mexiletine were $B_{\max }=29 \mathrm{fmol} / 10^{5}$ cells, $K_{\mathrm{d}}=26 \mathrm{nM}$; and $\mathrm{B}_{\max }=55 \mathrm{fmol} / 10^{5}$ cells, $K_{\mathrm{d}}=36 \mathrm{nM}$; respectively.

on [ $\left.{ }^{3} \mathrm{H}\right] \mathrm{BTXB} \mathrm{B}_{\max }$ and $K_{\mathrm{d}}$ during five separate experiments at each dose. The effect of mexiletine treatment on the number of binding sites was highly significant $(P<0.001)$ whereas mexiletine had no significant effect on the affinity in vitro of $\left[{ }^{3} \mathrm{H}\right]-$ BTXB for the sodium channel. The paired design of the experiments allowed expression of the data as the ratio of $B_{\max }$ of drug-treated rats to the $B_{\max }$ of placebo-treated rats. This $B_{\max }$ ratio also increased progressively and significantly with increasing doses of mexiletine $(P<0.001$; Table I). The possibilities that these changes in sodium channel number might in fact be due to spurious changes in cell recovery or in nonspecific changes in membrane-bound proteins were assessed by three methods. First, sodium channel numbers when expressed as $\mathrm{fmol} / 10^{5}$ viable, rod-shaped cells increased significantly after treatment with mexiletine (Table I). Second, sodium channel numbers when expressed as $\mathrm{fmol} / \mathrm{mg}$ protein also increased after treatment with mexiletine. For example, control rats had $147 \pm 22$ fmol sodium channels per $\mathrm{mg}$ protein, while rats

Table I. Mexiletine Dose-dependent Effect on Sodium Channel Number

\begin{tabular}{|c|c|c|c|c|}
\hline $\begin{array}{l}\text { Mexiletine } \\
\text { daily dose }\end{array}$ & $\mathbf{B}_{\max }$ & $\begin{array}{c}{\left[{ }^{3} \mathrm{H}\right] \mathrm{BTXB}} \\
K_{\mathrm{d}} \\
\end{array}$ & $\begin{array}{c}\left.{ }^{3} \mathrm{H}\right] \mathrm{BTXB} \mathrm{B}_{\max } \text { ratio } \\
\text { treated/control }\end{array}$ & $n$ \\
\hline & fmol/10 cells & $n M$ & & \\
\hline Control & $16 \pm 5$ & $29 \pm 7$ & - & 5 \\
\hline $50 \mathrm{mg} / \mathrm{kg}$ per $\mathrm{d}$ & $29 \pm 9$ & $22 \pm 6$ & $1.8 \pm 0.1$ & 5 \\
\hline $150 \mathrm{mg} / \mathrm{kg}$ per $\mathrm{d}$ & $54 \pm 9$ & $32 \pm 9$ & $3.4 \pm 0.6$ & 5 \\
\hline
\end{tabular}

Total specific binding of $\left[^{3} \mathrm{H}\right] \mathrm{BTXB}\left(\mathrm{B}_{\max }\right)$ and the affinity of $\left[{ }^{3} \mathrm{H}\right] \mathrm{BTXB}\left(K_{\mathrm{d}}\right)$ were determined on myocytes prepared from rats that had received placebo or mexiletine for $3 \mathrm{~d}$ as described in column 1 . The results are the mean values of five experiments $(x \pm S D)$ and are significant to $P \leq 0.001$ by ANOVA test. The paired nature of the experiment also allowed expression of the data as the ratio of $B_{\max }$ of drug-treated rats to the $B_{\max }$ of placebo-treated rats. The means of these ratios are shown $(\bar{x} \pm S D)$. 
treated with mexiletine $50 \mathrm{mg} / \mathrm{kg}$ per d had $230 \pm 30 \mathrm{fmol} \mathrm{so-}$ dium channels per $\mathrm{mg}$ protein $(P<0.01)$. Finally, the activity of the ouabain-sensitive sodium, potassium-activated ATPase was not significantly changed by subcutaneous mexiletine treatment. Control rats $(n=4)$ had $0.76 \pm 0.29 \mathrm{U}$ of ouabainsensitive ATPase per mg protein while rats treated $(n=4)$ with mexiletine $50 \mathrm{mg} / \mathrm{kg}$ per $\mathrm{d}$ had $0.62 \pm 0.17 \mathrm{U}$ of ouabain-sensitive ATPase per $\mathrm{mg}$ protein $(P=\mathrm{NS})$.

Time-dependence of mexiletine effect on sodium channel number. The time-dependence of the effect of mexiletine on sodium channel number was assessed by preparing cardiac myocytes from paired rats randomly assigned to treatment with mexiletine ( $50 \mathrm{mg} / \mathrm{kg}$ per d) or placebo for $0-6 \mathrm{~d}$. Fig. 2 shows the time-dependence of increase in the ratios of the $B_{\max }$ values of $\left[{ }^{3} \mathrm{H}\right] \mathrm{BTXB}$ binding in treated rats compared to untreated rats. Each point represents the mean ratio of three to four pairs of rats. Sodium channel number significantly increased with the duration of mexiletine treatment and reached a maximal value after $3 \mathrm{~d}$. The half-maximal value was reached after $1 \mathrm{~d}$.

Time-dependence of return to baseline. Paired rats were first treated for $3 \mathrm{~d}$ with mexiletine $(50 \mathrm{mg} / \mathrm{kg}$ per d) or placebo, then killed $0,2,4,5,6$, and $12 \mathrm{~d}$ after discontinuation of mexiletine treatment. Fig. 2 shows the time-dependent reduction in the ratio of $B_{\max }$ of mexiletine rats/ $B_{\max }$ of placebo rats after cessation of treatment. Each point represents the mean ratio of three to four pairs of rats. Sodium channel number significantly decreased with time after discontinuation of treatment and returned to the baseline value within $12 \mathrm{~d}$.

Effects of in vivo drug pretreatment on in vitro drug-receptor interactions. To assess whether treatment of rats with mexiletine results in a change in Class I drug-receptor affinity for mexiletine as well as a change in sodium channel number, pairs of rats were treated with mexiletine $(50 \mathrm{mg} / \mathrm{kg}$ per d) or placebo for $3 \mathrm{~d}$ and myocytes were subsequently prepared. Cardiac myocytes were incubated for $55 \mathrm{~min}$ in the presence of $15 \mathrm{nM}$ $\left[{ }^{3} \mathrm{H}\right] \mathrm{BTXB}$ and various concentrations of mexiletine. Fig. 3 illustrates a typical competition curve of $\left[{ }^{3} \mathrm{H}\right] \mathrm{BTXB}$ by mexiletine. The $\mathrm{IC}_{50}$ values for the in vitro inhibition of $\left[{ }^{3} \mathrm{H}\right] \mathrm{BTXB}$

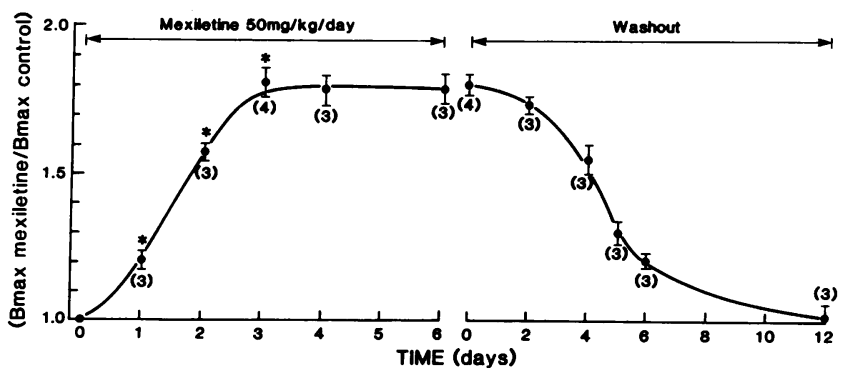

Figure 2. Time-course of the increase and decrease in the number of cardiac sodium channels during and after mexiletine treatment. (Left panel) Rats received mexiletine $(50 \mathrm{mg} / \mathrm{kg}$ per d) for the illustrated periods of time and myocytes were isolated from control and treated rats. (Right panel) After $3 \mathrm{~d}$ of mexiletine $(50 \mathrm{mg} / \mathrm{kg}$ per d) or placebo administration, the treatments were stopped $(t=0)$ and myocytes were isolated at the indicated times from control and treated rats. $\left[{ }^{3} \mathrm{H}\right]-$ BTXB Scatchard analysis was performed as described in Fig. 1. For each time the ratio $\left(B_{\max }\right.$ mexiletine/ $B_{\max }$ control) was determined by Scatchard analysis as described in Fig. 1 . The value for each time is the mean $\pm S D$. The numbers in brackets indicates the number of pairs of animals studied at each time. ${ }^{*} P<0.01$ by ANOVA.

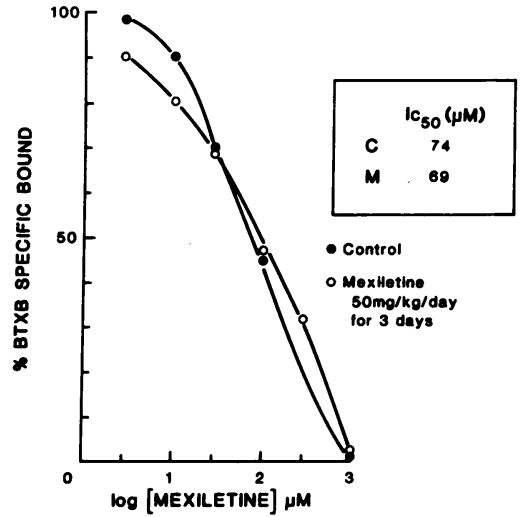

Figure 3. Effect of pretreatment with mexiletine on mexiletine affinity with its site in vitro. Myocytes were isolated from control rats (•) and from rats that had received $50 \mathrm{mg} / \mathrm{kg}$ per $\mathrm{d}$ of mexiletine for $\mathbf{3} \mathrm{d}$ (o). Myocytes $\left(6 \times 10^{5}\right.$ cells per tube) then were incubated with $1.3 \mu \mathrm{M}$ ATX, 0.13 mM TTX, $13 \mathrm{nM}\left[{ }^{3} \mathrm{H}\right] \mathrm{BTXB}$, and various concentrations of mexiletine. Specifi-

cally bound $\left[{ }^{3} \mathrm{H}\right] \mathrm{BTXB}$ was determined as described in Fig. 1. Mexiletine $\mathrm{IC}_{50}$ values were $74 \mu \mathrm{M}$ and $69 \mu \mathrm{M}$ for control and treated rats, respectively.

binding by mexiletine were $69 \mu \mathrm{M}$ and $74 \mu \mathrm{M}$ for rats treated with mexiletine and placebo, respectively. This experiment was repeated three times and the mean $\mathrm{IC}_{50}$ values were $70 \pm 7 \mu \mathrm{M}$ and $82 \pm 15 \mu \mathrm{M}$ for rats treated with mexiletine and placebo, respectively (NS).

To further characterize the nature of the inhibition of $\left[{ }^{3} \mathrm{H}\right]-$ BTXB binding by mexiletine, paired rats were treated with mexiletine $(50 \mathrm{mg} / \mathrm{kg}$ per $\mathrm{d}$ ) or placebo for $3 \mathrm{~d}$ and myocytes were subsequently prepared for Scatchard analysis of the nature of the inhibition of $\left[{ }^{3} \mathrm{H}\right] \mathrm{BTXB}$ binding by mexiletine. Fig. 4 shows that regardless of whether rats were pretreated with subcutaneous mexiletine or placebo, subsequent Scatchard
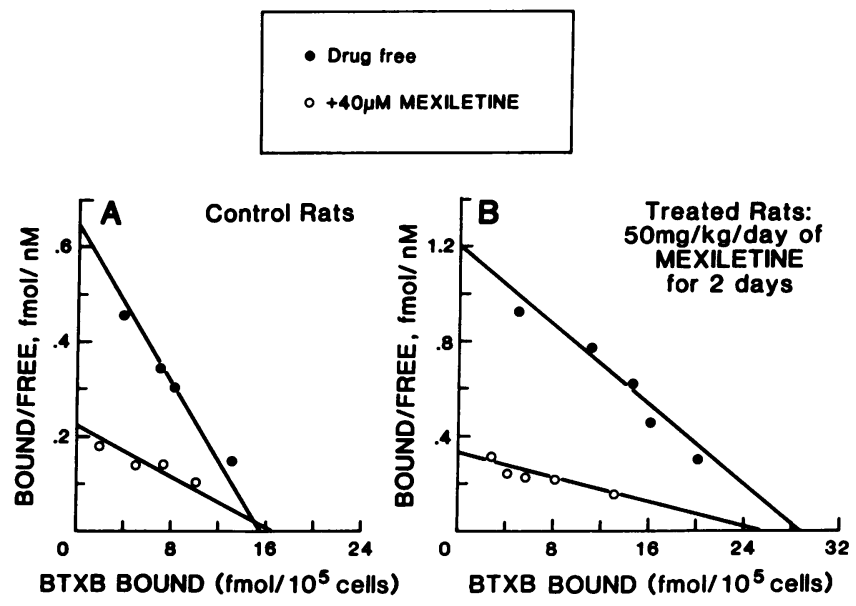

Figure 4. Effect of pretreatment with mexiletine on subsequent inhibition by mexiletine in vitro of $\left[{ }^{3} \mathrm{H}\right] \mathrm{BTXB}$ binding to cardiac myocytes. Myocytes $\left(6 \times 10^{5}\right.$ cells/point $)$ were isolated from control rats (Fig. $4 A$ ) and from treated rats that had received $50 \mathrm{mg} / \mathrm{kg}$ per d of mexiletine for $3 \mathrm{~d}$ (Fig. $4 \mathrm{~B}$ ). The myocytes were incubated in vitro as in Fig. 1 in absence (•) or in presence (o) of $40 \mu \mathrm{M}$ mexiletine and various concentrations of $\left[{ }^{3} \mathrm{H}\right] B$ BXB. Specifically-bound $\left[{ }^{3} \mathrm{H}\right] \mathrm{BTXB}$ was determined as described in Fig. 1. Linear regression best-fit values for the control myocytes (Fig. $4 \mathrm{~A}$ ) were $\mathrm{B}_{\max } 15 \mathrm{fmol} / 10^{5}$ cells, $K_{\mathrm{d}}$ $20 \mathrm{nM}$ in absence of mexiletine and $\mathrm{B}_{\max } 17 \mathrm{fmol} / 10^{5}$ cells, $K_{\mathrm{d}} 94 \mathrm{nM}$ in presence of mexiletine and for the treated rats (Fig. $4 B$ ) the best-fit values were $\mathrm{B}_{\max } 29 \mathrm{fmol} / 10^{5}$ cells, $K_{\mathrm{d}} 34 \mathrm{nM}$ in absence of mexiletine and $\mathrm{B}_{\max } 25 \mathrm{fmol} / 10^{5}$ cells, $K_{\mathrm{d}} 99 \mathrm{nM}$ in presence of mexiletine. Each Scatchard point was done in duplicate. Determinations of treated and control rat sodium channel numbers were done on the same day. 
analysis in vitro demonstrated that mexiletine $(40 \mu \mathrm{M})$ decreased the $K_{d}$ for [ ${ }^{3} \mathrm{H}$ ]BTXB binding by a comparable amount without a significant effect on $B_{\max }$.

Mexiletine levels. Serum concentrations of mexiletine were assessed 2 and $24 \mathrm{~h}$ after subcutaneous administration of 50 $\mathrm{mg} / \mathrm{kg}$ per $\mathrm{d}$ of mexiletine. The mexiletine concentrations were below the lower detectable limits of this HPLC method (10) $(0.1 \mu \mathrm{g} / \mathrm{ml})$. By comparison, the serum concentrations of mexiletine that are usually observed are $0.7-1.5 \mu \mathrm{g} / \mathrm{ml}$.

\section{Discussion}

We have shown that chronic in vivo treatment of rats with mexiletine, a drug that blocks cardiac sodium channels, induced a significant increase in the number of cardiac sodium channels. Mexiletine increased sodium channel number by up to threefold in a dose-dependent fashion. This increase in sodium channel number reached a maximum value after $3 \mathrm{~d}$ of treatment. After discontinuation of chronic treatment sodium channel number declined to the baseline values within $12 \mathrm{~d}$. These data suggest that the sodium channel is under physiologic regulation and that during chronic Class I antiarrhythmic drug treatment sodium channels may be increased.

Mexiletine levels. The undetectably low levels of serum mexiletine suggest that either sodium channel regulation in rats is exquisitely sensitive to the drug, or that subcutaneous drug administration produces effects that might not be seen with intravenous or oral drug administration. While the latter explanation cannot be eliminated, it is noteworthy that all control rats received sham injections, and that another membranebound protein (ATPase) did not exhibit similar changes. Thus the changes in sodium channel number appear to reflect a sodium channel-specific response to serum mexiletine, albeit at low concentrations.

Mechanism of increase in sodium channels. How mexiletine induces this increase in vivo remains speculative, but previous work by others suggests that this effect is also seen in vitro with rat muscle sodium channels. Sherman and Catterall (11) showed that exposure of rat myotubes to bupivicaine or tetrodotoxin significantly increased the number of cell-surface tetrodotoxin-sensitive sodium channels. They hypothesized that the increase in channels was mediated by a decrease in intracellular calcium, in turn due to a decreased number of action potentials in cells that were otherwise electrically active.

The origin of the upregulated channels is also unclear. The nerve sodium channel undergoes a complex series of metabolic modifications between translation and eventual cell-surface expression $(12,13)$ and there is a large intracellular pool of inactive alpha subunits (14). Furthermore, cAMP both inhibits (15) and downregulates (16) the cardiac sodium channel. The leisurely time-courses of both upregulation and return to baseline values in this report suggest that de novo synthesis and degradation of sodium channels are involved, although slow shuttling to and from an inactive intracellular pool (14) cannot be eliminated.

Clinical implications. This modulation of sodium channel number may have clinical relevance. We have previously reported that acute antiarrhythmic response to Class I drugs does not necessarily predict a similar favorable response during chronic oral therapy (1). This discrepancy occurred even though plasma concentrations of Class I antiarrhythmic drug were equivalent during acute and chronic therapy. The discrepancy between acute and chronic therapy in vivo may be related to a number of potential factors including differences in pharmacodynamic penetrance of myocardium and time-dependent accumulation of active metabolites but these results raise the possibility that resistance to Class I antiarrhythmic drugs may be in part modulated by an increase in the number of cardiac sodium channels.

\section{Acknowledgments}

This work was supported by grants from the Medical Research Council of Canada, Alberta Heritage Foundation for Medical Research, and Alberta Heart and Stroke Foundation. Robert Sheldon is a Canadian Heart Foundation Scholar and Henry J. Duff is a Scholar of the Alberta Heritage Foundation for Medical Research.

\section{References}

1. Duff, H. J., D. G. Wyse, D. Manyari, and L. B. Mitchell. 1985. Intravenous quinidine: relations among concentration, tachyarrhythmia suppression and electrophysiologic actions with inducible sustained ventricular tachycardia. Am. J. Cardiol. 55:92-97.

2. Boehringer-Ingelheim Co. 1976. Mexiletine investigational brochure.

3. Sheldon, R. S., N. J. Cannon, and H. J. Duff. 1987. A receptor for Type I antiarrhythmic drugs associated with rat cardiac sodium channels. Circ. Res. 61:482-497.

4. Kryski, A., K. A. Kenno, and D. L. Severson. 1985. Stimulation of lipolysis in rat heart myocytes by isoproterenol. Am. J. Physiol. 248:H208-H216.

5. Farmer, B. B., M. Mancini, E. S. Williams, and M. Watanabe. 1983. Isolation of calcium-tolerant myocytes from adult rat hearts: review of the literature and description of a method. Life Sci. 33:1-18.

6. Postma, S. W., and W. A. Catterall. 1984. Inhibition of binding of $\left[{ }^{3} \mathrm{H}\right]-$ batrachotoxinin A $20-\alpha$-benzoate to sodium channels by local anesthetics. Mol. Pharmacol. 25:219-227.

7. Sheldon, R. S., N. J. Cannon, and H. J. Duff. 1986. Binding of $\left[{ }^{3} \mathrm{H}\right]$ batrachotoxinin A benzoate to specific sites on rat cardiac sodium channels. Mol. Pharmacol. 30:617-623.

8. Monahan, A. S., and L. R. Jones. 1982. Characterisation of the intrinsic cAMP-dependent protein kinase activity and endogenous substrates in highly purified cardiac sarcolemma vesicles. J. Biol. Chem. 257:10052-10062.

9. Lowry, O. H., N. J. Rosebrough, A. L. Farr, and R. J. Randall. 1951. Protein measurements with the Folin phenol reagent. J. Biol. Chem. 193:265275.

10. Kelly, R., P. Christmore, and S. L. Jacob. 1981. Measurement of mexiletine in plasma by high performance chromotography. Ther. Drug Monit. 3:279286.

11. Sherman, S. J., and W. A. Catterall. 1984. Electrical activity and cytosolic calcium regulate levels of tetrodotoxin-sensitive sodium channels in cultured rat muscle cells. Proc. Natl. Acad. Sci. USA. 81:262-266.

12. Schmidt, J. W., and W. A. Catterall. 1987. Palmitylation, sulfation, and glycosylation of the $\alpha$ subunit of the sodium channel. Role of post-translational modifications in channel assembly. J. Biol. Chem. 262:13713-13723.

13. Waechter, C. J., J. W. Schmidt, and W. A. Catterall. 1983. Glycosylation is required for maintenance of functional sodium channels in neuroblastoma cells. J. Biol. Chem. 258:5117-5123.

14. Schmidt, J. W., S. Rossie, and W. A. Catterall. 1985. A large intracellular pool of inactive Na channel $\alpha$ subunits in developing rat brain. Proc. Natl. Acad. Sci. USA. 82:4847-4851.

15. Schubert, B., A. M. J. Van Dongen, G. E. Kirsch, and A. M. Braun. 1989. Beta-adrenergic inhibition of cardiac sodium channels by dual G-protein pathways. Science (Wash. DC). 245:516-519.

16. Taouis, M., R. S. Sheldon, and H. F. Duff. 1990. Cyclic AMP-dependent reduction of $\left[{ }^{3} \mathrm{H}\right]$ Batrachotoxinin (BTXB) binding to the cardiac sodium channel. Circulation. (Supp III)82:727. 